\author{
A R T I C L E S
}

\title{
THE MEANING OF THE NAATA + INFINITIVE CONSTRUCTION IN BASSE MANDINKA
}

\author{
ALEXANDER ANDRASON
}

Aвstract: Alexander Andrason. The Meaning of the NAATA + Infinitive Construction in Basse Mandinka. Lingua Posnaniensis, vol. LIV (1)/2012. The Poznań Society for the Advancement of the Arts and Sciences. PL ISSN 0079-4740, ISBN 978-83-7654-103-7, pp. 7-19.

Purpose: The present paper aims at providing a detailed description of values and uses offered by the NAATA form - an analytic Mandinka construction formed by means of the auxiliary naa 'come', employed itself in the so-called ' $T A$ tense', and the infinitive of the main "meaning" verb. In that manner, we intend to rectify an important lacuna in grammatical studies of the Mandinka language which have almost entirely ignored the issue of the NAATA locution.

Method: A detailed map of the semantic content of the NAATA form will be designed, specifying its temporal, taxis, aspectual and modal implications, as well as certain textual properties. All the values will be illustrated by instructive examples provided by ten native Mandinka speakers (i.e. residents of Basse and neighboring villages: Manne Kunda, Bassending, Mansajang and Kaba Kama) and collected by the author in 2010 and 2011.

Results: The evidence shows that the meaning of the NAATA construction corresponds to a present perfect (resultative, iterative, inclusive, experiential and indefinite), to a past tense (immediate, recent, general and remote) and to a perfective aspect (punctual, terminative and ingressive; less commonly the locution approximates a simple past). Additionally, the formation expresses certain modal concepts, such as non-intentionality, accidentality or spontaneity of a corresponding perfect or past event. As far as textual properties are concerned, the NAATA form is found both in discourse and narration, being able in the latter case to introduce events of the narrative foreground.

Conclusion: The author demonstrates that the values displayed by the construction (with an exception of the modal senses) can be connected and a definition, which exceeds a simple inventory of uses, may be provided if one views the locution from a dynamic evolutionary perspective, i.e. as a manifestation of one of the developmental scenarios governing the grammatical evolution of original resultative constructions, namely as a realization of the anterior path. Furthermore, the modal senses of the NAATA form may be related to the anterior trajectory (and to its meanings-stages) if we make use of the evidential path, an evolutionary possibility which links the grammatical life of resultatives with determined modal domains. This latter proposition, however, needs a more profound analysis and will constitute one of the research activities, conducted by the author in the future.

Alexander Andrason, University of Stellenbosch, Private Bag X1, 7602 Matieland, South Africa; University of Iceland, v/ Suðurgötu, 101 Reykjavík, Iceland, aleksand@hi.is 


\section{INTRODUCTION}

The present paper aims at providing a detailed description of values and uses offered by an analytic Mandinka ${ }^{1}$ construction formed by means of the auxiliary naa 'come' - employed itself in the so-called ' $T A$ tense' (sometimes referred to as a completive-perfective aspect or past tense; see Macbrair 1842: 16; Rowlands 1959; Gamble 1987: 17; Colley 1995: 15; CREISSELS 2008: 77; 2010a: 3; 2010b: 3 and 2007 and ANDRASON 2011c) ${ }^{2}$ - and the infinitive of the main "meaning" verb (cf. example 1 below; henceforth the expression will be labeled 'NAATA gram'). ${ }^{3}$

$$
\begin{array}{ll}
\text { A naata } & \text { taa }^{4} \\
\text { he come-TA } & \text { go } \\
\text { He went } &
\end{array}
$$

Despite the fact that the formation is commonly used both in colloquial-discursive situations and in narrative (written or recited) texts, most scholars paid no attention to it in their studies of the Mandinka verbal system. De facto, the locution has almost entirely been overlooked or marginalized in - yet highly valuable - grammars, teaching manuals and scientific articles available thus far (e.g., Macbrair 1842; Rowlands 1959; Creissels 1983; Gamble 1987; Colley 1995; Mandinka Learning Manual 2002; DrAMÉ 2003 etc.). This article rectifies this deficiency in the grammatical description of the Mandinka language and offers a comprehensive analysis of the semantics of the NAATA gram.

One shall acknowledge that our evidence - and hence conclusion reached in the last part of the article - makes reference to a Mandinka variety spoken in the eastern part of Gambia,

1 Mandinka - an idiom widely spoken in Gambia, Senegal and Guinea Bissau - is usually classified as the westernmost variant of the Manding cluster (WILSON 2000: 109) which, in turn, forms a part of the Western branch of the Mande family (Kastenholz 1996: 281; Vydrine et al. 2000; Williamson \& Blench 2000). Manding, itself, consists of several regional varieties such as, aside from Mandinka, Bambara, Malinké or Jaahanka. The total number of speakers of Mandinka amounts to 1,346,000 of whom 510,000 reside in Gambia (the presented numbers are based on data gathered in 2006; cf. LewIs 2009).

2 The $T A$ gram is formed by adding the suffix $-t a$ to the verb, as in our case: naa 'to come' > naata 'has (have) come/came'. The TA formation displays a broad range of uses. It approximates the categories of present perfect, past (perfective, simple and durative), pluperfect, future perfect (exclusively in certain subordinated clauses), stative and present (for a complete review of meanings conveyed by the TA expression see ANDRASON 2011c).

3 The NAATA construction should be clearly distinguished from a literal periphrasis composed by the verb naa 'come' in the $T A$ form (i.e. naata) and an infinitive with a postposition $l a$, alternatively analyzed as an infinitive marker:

$\begin{array}{lllllll}\text { a. N naata } & \text { bukoo safee } & \text { la } & & \\ \text { I come-TA } & \text { book } & \text { write } & \text { to } & & \\ \text { I came to write the book } & & & & & & \\ \text { b. Fo i nata } & \text { le } & \text { ka ǹ } & \text { kasaara bay? } \\ & \text { whether you come-TA } & \text { EMPH } & \text { to } & \text { us } & \text { destroy QUES }\end{array}$

It should be noted that in the above example, the word bay stands for a question particle and is glossed QUES.

4 The relevant NAATA forms (i.e. the auxiliary naa + a meaning verb) will be given in bold type.

5 The auxiliary naa in the NAATA formation will be glossed respecting its origin, i.e. 'come-TA', i.e. the verb naa 'come' in the $T A$ tense. 
namely in the capital of the Upper River Region, Basse, and in neighboring villages (Manne Kunda, Bassending, Mansajang and Kaba Kama). This variation will henceforth be labeled as Basse Mandinka in order to differentiate it from 'Standard Mandinka' - a uniform normalized version of Mandinka employed in Gambia in dictionaries, ${ }^{6}$ grammar manuals, ${ }^{7}$ religious Christian and Islamic literature ${ }^{8}$ as well as in television or the Internet. The vernacular used in Basse - even though highly similar to that literary "norm" - shows certain discrepancies. For instance, the voiced velar stop [g] - missing in the standardized language - functions as a genuine phoneme in Basse Mandinka (e.g. gaadiinoo or Gambiya instead of the standard forms kaadiinoo 'garden' and Kambiya 'Gambia'). Likewise, in Basse Mandinka possessive or pronominal constructions may be derived not only by means of the postposition la (a typical technique in the normalized language: Laamini la bukoo 'Lamin's book') but also by employing the morpheme ye (Laamini ye bukoo 'Lamin's book'; for a complete analysis of differences between Basse Mandinka and Standard Mandinka, see ANDRASON 2012b: 9-10). ${ }^{9}$

All the examples offered in the present article were collected in the Basse district in 2010 and 2011 during an extensive research project dedicated to work on the grammar of Basse Mandinka (cf. AndRASON 2012b). These linguistic illustrations have been provided by the following ten native Mandinka speakers, residents of Basse or the four - previously mentioned - neighboring villages: ${ }^{10}$ Keba Suso (13 years old, primary school student, Bassending), Malick Suso (18, high school student, Bassending), Musa Yaffuneh (24, watchman, Basse), Lamin Manneh (25, university student, Manneh Kunda), Mamanding Sanyang (27, nurse assistant, Basse), Musa Sanneh (29, driver, Kaba Kama), Baba Kamara (30, teacher, Mansajang), Saikou Drammeh (44, nurse, Basse - originally from Serekunda but living in Basse for ten years), Kumba Jallow (56, cook, Mansajang) and Mariama Mendi (32, nurse, Mansajang - originally from Fulla Bantang). ${ }^{11}$

Finally, it should be noted that our examples are threefold: some were spontaneously formulated by speakers; others were pronounced under the request of the author (the informant was asked to translate a certain proposition or to express determined meaning); finally, a number of examples was motivated by written Christian and Muslim texts (the person was asked to pronounce a given sentence and, if needed, reformulate and comment on it).

6 For instance, Mandinka English Dictionary (1988) and (1995).

7 See A Practical Orthography of Gambian Mandinka (1988), LüCK \& Henderson (1993) or Mandinka Learning Manual (2002).

8 For example, Kambey Kutoo 'New Testament' (1988), Kambey Kotoo 'Old Testament' (1998) or Selections from the Writings of the Promised Messiah (1988).

9 Despite a number of distinctive traits, it may not be accurate to consider the Basse variety a dialect of Standard Mandinka: the differences are mostly phonetic and lexical. On the other hand, it is obvious that the classification of a given linguistic organization as a dialect - or as a language - is not solely a linguistic issue, but rather is conditioned by several political, sociological and economic factors. Furthermore, it should be observed that some of the mentioned dissimilarities are not restricted to the Basse area but, quite the reverse, can be found in other parts of Gambia.

10 The list has been arranged following the age of the informants introducing also the information concerning their occupation and residence place.

11 The last two informants are entirely bilingual: Fula-Mandinka and Manjago-Mandinka. Their ethnic background is Fula and Manjago respectively. 


\section{EVIDENCE}

In the present section we will design a meticulous map of the entire semantic content of the NAATA formation. This means that all specific and individual temporal, taxis, aspectual and modal meanings ${ }^{12}$ - as well as some textual properties - displayed by the form will be presented and illustrated by instructive examples, provided by the above-mentioned informants. $^{13}$

The NAATA formation offers various values which cover the semantic domain that usually characterizes the category of present perfects or present anteriors. For instance, approximating a resultative present perfect of current relevance, the gram expresses previous - already completed - actions whose accomplishment affects the present state of affairs. Put differently, certain effects of a formerly performed activity are currently available, determining the condition of the subject and his or her reality. Nevertheless, it must be emphasized that the reading of the NAATA form in these cases is invariably dynamic and the prominence is given to the prior action while the resulting state is merely suggested.

$$
\begin{aligned}
& \text { İ naata kendeyaa } \\
& \text { they come-TA be.well } \\
& \text { They have been cured (and they are well now) }
\end{aligned}
$$

$\begin{array}{lll}\text { A } & \text { naata } & \text { faa } \\ \text { he } & \text { come-TA } & \text { die }\end{array}$

He has died (and he is dead now)

$\begin{array}{llllll}\text { Saayin } & n & \text { naata } & \text { muru } & \text { karambuy } & \text { to kotenke } \\ \text { now I } & \text { come-TA } & \text { return } & \text { school to again }\end{array}$

Now I have returned to school (and I am at school, i.e. I am a student)

${ }^{12}$ It shall be noted that the partition of the total meaning of the NAATA gram into atomic senses is not arbitrary. The labels that are employed in the "decomposition" of the overall polysemy of the gram into more basic values follow three main principles. First, our categories respect the terminology commonly used in grammatical descriptions of African languages (cf. NuRSE 2008 and WALTKE \& O'CONNOR 1990) and in studies dedicated to general linguistics (cf. Bybee et al. 1994 and Haspelmath et al. 2001). Second, in certain languages, our labels correspond to realist and independent categories - they typologically exist. And third, these specific categories sometimes have a practical application. Namely, they enable linguists to establish an exact range of correspondence between constructions whose semantic potential, although similar, is not identical. For example, the category of an inclusive and hodiernal (and, in certain case, hesternal) definite past gives us a possibility to determine the precise difference in meaning between the English and Spanish present perfects (BYBEE et al. 1994: 98). In English, the present perfect gram (I have done) usually fails to appear with the sense of a definite hodiernal-hesternal past, while in Spanish a typologically equivalent formation (he hecho) does not provide the value of an inclusive perfect. The remaining perfect uses (resultative, experiential, iterative and indefinite) are conveyed by the English and Spanish form.

${ }^{13}$ In order to demonstrate that the NAATA construction provides a given sense, we will construct a context where this value is activated. Thus, when we state that the NAATA form functions as a present perfect, past perfect, future perfect or past, we mean that it is compatible with an environment where such nuances are made evident and palpable. Consequently, in our categorizations, the labels such as 'present perfect', 'past perfect', 'future perfect' etc. make reference to semantic domains. Inversely, they do not imply that the formation is an invariant present perfect, past perfect or future perfect grammatical category. This technique of decomposition of the total meaning into atomic senses harmonizes with a principle of cognitive linguistics whereby the overall meaning of a gram - its entire polysemy - constitutes a context induced phenomenon (see above in this section; cf. likewise DAHL 2000: 6-7, 14; Croft \& CRUSe 2004: 258; Evans \& Green 2006: 352-353, 368 and NiKIFORIDOU 2009: 16-17). 
The formation may also appear with the force of an experiential present perfect, indicating that a given activity forms a part of the subject's experience, having occurred at least once during his or her life time. In such cases, the value of current relevance remains palpable while the properly resultative meaning fails to be present:

\begin{tabular}{|c|c|c|c|c|c|}
\hline $\begin{array}{l}\text { Fo } \\
\text { whether } \\
\text { Has he e }\end{array}$ & $\begin{array}{l}\text { a } \\
\text { he } \\
\text { ver }\end{array}$ & $\begin{array}{l}\text { nene } \\
\text { ever } \\
\text { ne it? }\end{array}$ & $\begin{array}{l}\text { naata } \\
\text { come-TA }\end{array}$ & $\begin{array}{l}\text { a } \\
\text { it }\end{array}$ & $\begin{array}{l}\text { ke? } \\
\text { do }\end{array}$ \\
\hline $\begin{array}{l}\text { Haa, } \\
\text { yes }\end{array}$ & & $\begin{array}{l}\text { naata } \\
\text { come-TA }\end{array}$ & $\begin{array}{l}\text { ke } \\
\text { occur }\end{array}$ & $\begin{array}{l}\text { siiñaa } \\
\text { time }\end{array}$ & $\begin{array}{l}\text { kilin! } \\
\text { one }\end{array}$ \\
\hline
\end{tabular}

The construction may likewise indicate that resultative or experiential actions have occurred several times or repeatedly, thus approximating the category of an iterative present perfect:

$$
\begin{aligned}
& \text { A naata ke bii siiñaa naani } \\
& \text { it come-TA occur today time four } \\
& \text { It has occurred today four times }
\end{aligned}
$$

The gram seems to be able to carry out the sense of an inclusive perfect, suggesting that a certain activity or condition began at an overtly specified time in the past but has continued into the present moment in an uninterrupted manner (cf. the following use of the Present Perfect in English: I have lived here for 10 year or I have lived here since 2000):

$$
\begin{array}{lllll}
N & \text { naata jiyaa } & \text { jay sanji } & \text { fula } \\
\text { I come-TA be.accommodated } & \text { here } & \text { year } & \text { two } \\
\text { I have lived here for two years (I still live here) } &
\end{array}
$$

A naata kuuray tili naani
he come-TA besick day four

He has been sick for four days (he is still sick)

$\begin{array}{llllll}\text { Kabirin } 1994 & \text { ñin ne } & \text { naata } & \text { ke n na dookuwo ti } \\ \text { since } 1994 & \text { this EMPH } & \text { come-TA } & \text { be I of }{ }^{15} \text { job } & \text { EXIS }^{16}\end{array}$

Since then, this has been my job

Kabirin 2000 a naata moolu karandi
since 2000 she come-TA people teach
Since 2000 she has taught / been teaching people

Mandinka kayo la
Mandinka language $\quad$ with/at ${ }^{17}$
the Mandinka language

${ }^{14}$ The lexeme ne (a phonetic variant of $l e$ ) is an emphatic particle which will be glossed as EMPH.

15 The slot $n$ na (i.e. $n$ 'I' + la of'; on the entity la see footnote 17 below) functionally corresponds to a possessive pronoun of the 1st person singular such as 'my' in English.

16 The lexeme $t i$ - besides functioning as a postposition 'into' - is an existential particle that accompanies certain verbs with the meaning of 'be' or 'become' (e.g., $m u$ or $k e$ ). It will be glossed as EXIS.

${ }_{17}$ The word $l a$ is a postposition with a broad range of uses and values. Hereafter, we will gloss it as 'with/at' or - when employed in possessive (genitival) constructions - as 'of'. 
The locution can also function as an indefinite perfect or, employing an alternative label, indefinite past. In that case, the gram expresses events that unquestionably belong to the past time sphere, without overly specifying their temporal position, for instance by means of adverbs or adverbial locutions (e.g., yesterday, last week, a week ago etc.).

$$
\begin{aligned}
& \mathrm{N} \text { taata Basse anin } \mathrm{n} \text { naata kewo ñin faa } \\
& \mathrm{I} \text { went Basse and I come-TA } \\
& \text { I went to Basse and I killed the man }
\end{aligned}
$$

Besides that the NAATA form appears in various typically perfect functions, the construction is likewise commonly employed as a definite past tense. In that case, the past moment is specified by means of certain adverbs and adverbial locutions or it is inferred from to a general context, being, for instance, a part of a narrative flow of events. As for the temporal distance from the speaker or narrator's here-and-now, it may range from recent (e.g., immediate, hodiernal and hesternal; cf. 7a) to general (e.g., during a person's life; cf. 7b and 7c) and remote (e.g., ancient or legendary past; cf. 7d and 7e). This means that the NAATA gram may introduce activities which refer to any temporal point in the past, either nearby or distant.

$$
\begin{aligned}
& \text { A naata faa bii } \\
& \text { he come-TA die today } \\
& \text { He died today } \\
& \begin{array}{llll}
\text { Ì } & \text { naata } & \text { faa } & \text { seruy } \\
\text { they } & \text { come-TA } & \text { die } & \text { last.year }
\end{array} \\
& \text { They died last year } \\
& \text { Sanji } 1988 \text { n naata sawuy Saragosa saatewo to } \\
& \text { year } 1988 \text { I come-TA move Zaragoza city to } \\
& \text { In } 1988 \text { I moved to Zaragoza } \\
& \begin{array}{llllll}
\text { Wo waatoo } & \text { le } & \text { mansa } & \text { naata } & \text { taa } & \text { Damasikusi } \\
\text { that time } & \text { EMPH king } & \text { come-TA } & \text { go } & \text { Damascus }
\end{array}
\end{aligned}
$$

At that time, the king went to Damascus

Judasi mey nata ke Yeesu jamfaalaa ti
Judas who come-TA be Jesus traitor

In addition to its rather regular use in discourse and dialogues (cf. examples 2-6), as a past tense, the gram is also abundantly found in narrative - both written and recited - passages. In these instances, it may act as a narrative form of foreground introducing events of the narrative backbone. This use may be illustrated by the following examples extracted from the Mandinka Bible and subsequently recited by native speakers:

$$
\begin{aligned}
& \text { A naata faa Noora Kulino le la } \\
& \text { he come-TA be.filled spirit holly EMPH with/at } \\
& \text { He was filled with the Holy Spirit }
\end{aligned}
$$

$\begin{array}{llllll}\text { A naata bo } & \text { jee } & \text { ka } & \text { taa } & \text { saatewo } & \text { to } \\ \text { he come-TA } & \text { come.from there } & \text { to } & \text { go }^{18} & \text { village } & \text { to } \\ \text { He came from there to the village } & & & & \end{array}$

${ }^{18}$ Nowadays, the slot $k a$ taa (originally 'to go') functionally approximates the English preposition 'to'. 
$(8 \mathrm{c})$
A naata Yehohasi samba Misira, bitun a faata jee
he come-TA Jehoahaz take Egypt, and.then he died there
Jehoahaz was taken to Egypt, and he died there

In such narrative uses, the gram is commonly preceded by the particle bitur '(and) then':

(9a)

$\begin{array}{llll}\text { Bituy Yahuuda } & \text { bankoo } & \text { moolu } \\ \text { and.then Judea land } & \text { people } \\ \text { And then the people of Judea }\end{array}$

$\begin{array}{llll}\text { naata } & \text { Yosiya } & \text { dinkewo } & \text { Yehohasi tombon } \\ \text { come-TA } & \text { Josiah } & \text { son } & \text { Jehoahaz choose }\end{array}$

chose Jehoahaz the son of Josiah

$\begin{array}{llllllllll}\text { Bituy ì naata } & \text { a } & \text { dinkewo } & \text { ke } & \text { a } & \text { noo } & \text { to } & \text { mansa } & \text { ti } \\ \text { then they } & \text { come-TA } & \text { his } & \text { son } & \text { do } & \text { his } & \text { place } & \text { at } & \text { king } & \text { into }\end{array}$

Then they made his son king in his place

In respect to the aspectual value of the NAATA periphrasis, the construction most commonly denotes perfective - unique and punctual, terminative or ingressive - events:

(10a) A naata ke kabirin a be saatewo doo to

it come-TA happen when he is town certain at

It happened when he was in a certain town

(10b) A naata foo a niyo la

he come-TA loose his soul with/at

He lost his [own] soul

(10c) Wo kumoo naata ke hadamadino le ti,

that word come-TA become human.being EMPH EXIS,

The word became human

$\begin{array}{llllll}\text { aduy } & \text { ate } & \text { naata } & \text { tara } & \text { ǹ } & \text { kono } \\ \text { and.then } & \text { it } & \text { come-TA } & \text { dwell } & \text { us } & \text { among }\end{array}$

and dwelt among us (i.e.: The word made his home among us)

(10d) Ì naata a fo mansa ye ko:

they come-TA it say king to saying

They told the king that...

(10e) Elisa naata taa Damasikusi

Elisha come-TA go Damascus

Elisha went to Damascus

(10f)

Wo to le moolu seewoota,

that at EMPH people rejoiced,

Then the people rejoiced;

$\begin{array}{llll}\text { adun saatewo naata } & \text { tenkuno soto } \\ \text { and town } & \text { come-TA } & \text { quietness } & \text { get }\end{array}$

and the town became peaceful (lit.: gained the peacefulness)

(10g) Wo koolaa, $\mathrm{n}$ nata sunkutu doo futuu,

that after, I come-TA girl another marry

After that, I married another girl 
(10h)

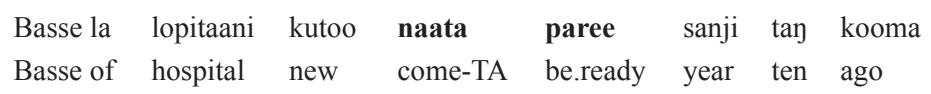

The new hospital of Bass became ready ten years ago

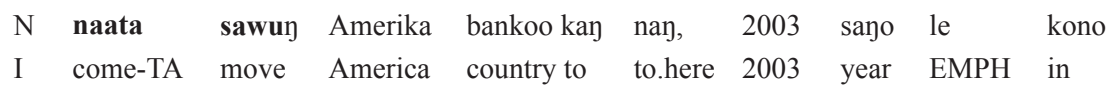

I moved to the United States of America in 2003

In certain cases, the NAATA formation - employed in the past perfective function - is equivalent to the TA construction, derived from punctual telic verbs. This means that in the following examples, the slots naata faa or naata taa and the forms faata or taata display the identical perfective force 'he died' and 'he went', respectively:

$$
\begin{aligned}
& \text { Bitun ate naata faa } \\
& \text { then he come-TA die } \\
& \text { Then he died } \\
& \text { Bituy ate faata } \\
& \text { then he die-TA } \\
& \text { Then he died }{ }^{19}
\end{aligned}
$$

A naata taa
he come-TA go
He went to Basse

A taata Basse
he go-TA Basse
He went to Basse

This perfective - either completive-terminative or ingressive - value may clearly be observed if we compare the NAATA formation with the use of an analogous verb (with the exception of telic verbs in determined contexts, cf. the previous paragraph) in the $T A$ or $Y E^{20}$ grams. These constructions - besides appearing with a perfective force - may also act as simple preterites or even, when derived from some roots, as durative past tenses (cf. ANDRASON 2011c and 2012c). On the contrary, the value of the NAATA periphrasis is most commonly perfective. This can be illustrated by the following examples where the verbs kuuray or saasaa 'be sick' and koyi 'be white, clear' appear in the NAATA gram and in the $T A$ construction. While in the former case, the significance is clearly perfective (ingressive 'get'), in the latter, two readings are equally possible: one perfective (analogous to the previous case) and the other - very frequent and, in fact, dominant - stative or durative:

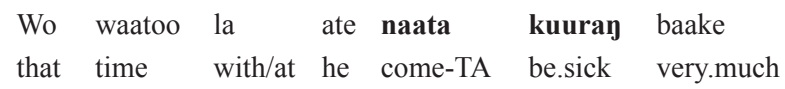

In those days, he became sick (cf. the Latin and Greek forms: aegrotavit $[$ Perfectum $=$ perfective past] and $\dot{\eta} \rho \rho \dot{\omega} \sigma \tau \sigma \varepsilon v$ [Aorist $=$ perfective past]

$\begin{array}{llll}\text { Wo waatoo la } & \text { ate kuuranta le } \\ \text { that time } & \text { with/at he be.sick-TA EMPH }\end{array}$

In those days, he was sick (cf. the Latin and Greek forms: erat [imperfective past] and $\tilde{\eta} v$ [imperfective past])

${ }^{19}$ However, faata may also mean 'he is/was dead' (cf. example 13.d below).

${ }^{20}$ The $Y E$ formation is formed by means of the auxiliary $y e$ (or its variant in the first person singular and plural: $\eta a$ and $\eta \grave{a}$ respectively), e.g. $a$ ke 'to do' $>$ a ye $a$ ke 'he has done it / he did it'. The lexeme ye will be glossed 'YE'. 
$(12 \mathrm{c})$

\begin{tabular}{|c|c|c|c|}
\hline & & & a \\
\hline
\end{tabular}

Few days later, Lamin got very sick (cf. the Polish translation: zachorowat [perfective past])

Kunuy, a saasaata bake

yesterday he be.sick-TA very.much

Yesterday he was very sick (cf. the Polish translation: chorowat [imperfective past])

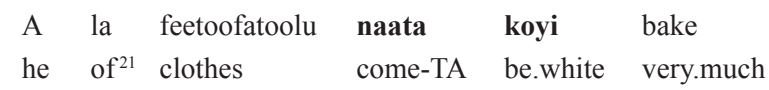

His clothes turned very white (cf. the Polish translation: staty się [perfective past] biate)

Nin dendinkoo koyita nuy

this shirt be.white-TA then

This shirt was white (cf. the Polish translation: byla [imperfective past] biała)

When the temporal reference is unspecified or general, the NAATA form may function as a perfective past or a dynamic perfect while the $T A$ and $Y E$ constructions also provide additional stative (present or durative past) values.

$$
\begin{aligned}
& \text { A naata kodoo soto } \\
& \text { he come-TA money get } \\
& \text { He has obtained money / He obtained money }
\end{aligned}
$$

$\begin{array}{lll}\text { A ye } & \text { kodoo } & \text { soto } \\ \text { he } \quad \text { YE } & \text { money } & \text { obtain } \\ \text { He has money } & & \end{array}$

$\begin{array}{lll}\text { A } & \text { naata } & \text { fa } \\ \text { he } & \text { come-TA } & \text { die }\end{array}$

He has died / He died
A faata
he die-TA
He is/was dead

This interaction of the NAATA form (perfective or dynamic perfect expression) and the $T A$ gram (a construction which, besides perfective and perfect uses, also admits stative, durative and simple present values) may be illustrated by the following example where the two locutions coincide:

$$
\begin{array}{llllll}
\text { N } & \text { fankata } & \text { le. } & \text { Nte } & \text { naata } & \text { fankoo soto le } \\
\text { I } & \text { be.rich-TA } & \text { EMPH. I } & \text { come-TA } & \text { riches have EMPH }
\end{array}
$$

The dynamic perfective sense - as contrasted with the motionless stative value - may be observed in the following use of the verb a loy 'to know'. In the $Y E$ formation, this root most commonly conveys the stative meaning of knowing ( a ye a loy 'he knows' or 'he knew'). However, when employed in the NAATA gram, the value of the entire locution corresponds either to a dynamic perfect or to a perfective past, offering a strong ingressive sense 'get to know, understand, realize'. 'his'.

${ }^{21}$ The sequence $a$ la (literally 'he of') equals the English possessive pronouns of the $3 \mathrm{rd}$ person singular 
(15a)

$$
\begin{aligned}
& \mathrm{N} \text { ka tu } \quad \text { kamfaarin, } \\
& \text { I used.to continue being.angry } \\
& \text { I continued being angry (I was angry / I used to be angry), }
\end{aligned}
$$

$$
\begin{array}{lllllll}
\text { fo labayo } & \text { la } & \mathrm{n} & \text { naata } & \text { a } & \text { loy } & \text { ko, } \\
\text { until last } & \text { with/at } & \text { I } & \text { come-TA } & \text { it } & \text { know } & \text { that }
\end{array}
$$

until finally I got to know (I understood) that

$\begin{array}{lllll}\text { kamfaa may nafaa } & \text { soto } n & \text { ye } \\ \text { anger not benefit has I } & \text { for }\end{array}$

anger had no benefit for me

$\begin{array}{lllllll}\text { Aduy } & \text { ì } & \text { naata } & \text { wolu } & \text { la } & \text { suuloolu } & \text { loy } \\ \text { and.then } & \text { they } & \text { come-TA } & \text { those } & \text { of } & \text { needs } & \text { know }\end{array}$

And then they got to know (understood / realized) their needs

$\begin{array}{lllllll}\text { Saayin ite } & \mathrm{mu} & \text { naatonkoo } & \text { le } & \text { ti } & \text { coocoo } & \text { kono } \\ \text { now you } & \text { are } & \text { leader } & \text { EMPH } & \text { EXIS } & \text { church } & \text { in }\end{array}$

Now you are the leader in the church

I naata Alla la ñin siloo lon naadii le?
you come-TA god of this way know how
EMPH
How did you get to know this way of God?

All of this clearly demonstrates that the NAATA formation is invariably dynamic in contrast to common static readings offered by certain roots in the $T A$ and $Y E$ grams.

Nevertheless, in some radically less common cases and certainly due to the lexical value offered by a specific verbal root, the sense of the NAATA form may approximate the category of a simple past: the event is portrayed in its entirety (as in the case of the perfective aspect), but punctual (either terminative or ingressive) sense is significantly less patent:

$$
\begin{array}{llllll}
\text { Seruy, } & \text { feetoo } & \text { juuraloo } & \text { naata } & \text { ke } & \text { Basse to } \\
\text { last.year } & \text { feast } & \text { celebration } & \text { come-TA } & \text { occur } & \text { Basse at }
\end{array}
$$

A celebration was held in Basse last year (i.e.: people celebrated a feast)

$$
\begin{aligned}
& \text { Moolu nata lafi ya } \quad \text { ì makoyi kayo } \begin{array}{l}
\text { ñin to } \\
\text { People come-TA want }
\end{array} \text { I.should them help language this in } \\
& \text { People wanted that I would help them in this language (i.e.: people wanted me to help them) }
\end{aligned}
$$

In addition to the values introduced thus far - which roughly correspond to determined uses of the TA and $Y E$ grams (cf. ANDRASON 2011c and 2012c) - the NAATA formation provides certain "modal" nuances. ${ }^{22}$ It indicates, especially in discourse, that a given perfect or past action has occurred spontaneously and accidentally, or due to the fact that the subject has changed his or her original intention:

$$
\begin{aligned}
& \mathrm{N} \text { naata naa } \\
& \text { I come-TA come } \\
& \text { It happened that I came (first, I was not going to come, but I came) } \\
& \mathrm{N} \text { naata a ke } \\
& \text { I come-TA it do } \\
& \text { It happened that I did it (first, I was not going to do it, but I did it) }
\end{aligned}
$$

${ }^{22}$ We employ the term 'modal' since, by using the construction, the speaker expresses his or her attitude toward the activity conveyed by the main "meaning" verb. We are, however, aware of the fact that the gram is not a grammatical mood sensu stricto. 


\section{CONCLUSION}

Let us first recapitulate the evidence introduced in the previous part of the article. The meaning of the NAATA construction frequently corresponds to a dynamic present perfect (resultative, iterative, experiential, inclusive and indefinite), to a past tense (immediate, recent, general and remote) and to a perfective aspect (punctual, terminative and ingressive). No less frequent are uses where the formation expresses the non-intentionality, accidentality or spontaneity of a corresponding perfect or past event. In all of the above-mentioned cases, the meaning of the gram is invariably dynamic. This dynamic undertone is clearly related to the dynamic sense of the auxiliary naa 'come'. Besides these typical values, the formation may rarely approximate the category of a simple past - a preterite. Finally, as for its textual properties, the locution is found both in discourse and narration, being able, in the latter case, to introduce events of the narrative foreground.

Having presented all individual values offered by the NAATA formation, the following question may be asked: is it possible to relate the particular senses and, consequently, grasp the gram's overall meaning in its totality? Put differently, can we explain the construction as a solid rational and homogenous phenomenon instead of offering a classification which is limited to a mere taxonomy of uses?

The connection between all values offered by the NAATA locution is evident - and thus a definition which exceeds a simple inventory of values becomes feasible - if one views the gram from a dynamic evolutionary perspective, i.e. as a manifestation of certain developmental processes. Namely, all concrete atomic values almost perfectly match stages on the anterior path: one of the developmental scenarios governing the grammatical evolution of original resultative constructions (cf. BYBEE et al. 1994; DAHL 2000 and ANDRASON 2011a and 2012a). According to the anterior path, resultative grams first develop into perfects (in the beginning, resultative and inclusive present perfects, later experiential and indefinite varieties) and next into past tenses (initially, recent and discursive, subsequently general, remote and narrative ones). When passing from the domain of a present perfect to the "realm" of a definite past tense, original resultative locutions frequently (although not always) acquire an explicit aspectual marking and function as perfective pasts (for a far more detailed treatment of the anterior path, see ANDRASON 2011a and 2012a). The values - various perfect, past and perfective meanings - offered by NAATA construction nearly ideally harmonize with the anterior path and match its consecutive stages. As a result, the formation may be classified in its totality as a manifestation of the anterior diachrony, covering the phases of this path from the resultative perfect to the narrative past tense. Such a label enables us to encapsulate and preserve the entire semantic potential of the gram. ${ }^{23}$

${ }^{23}$ Such a use of evolutionary processes in studying contemporary data where the diachronic framework constitutes an explanation for forms that are all viewed as synchronic has been referred to as 'panchrony' (ANDRASON 2011b). In linguistics, one usually distinguishes two types of analysis: diachrony and synchrony. The former presents the historical development of a given grammatical element while the latter depicts its contemporary behavior. Panchrony combines these two - usually understood as separated - methods, unifying them into a single global view which may be applied for the description of historically inert grammatical objects and systems, explaining them as dynamic "time-sensitive" phenomena. Under this view, synchrony is understood as a static materialization of a diachronic progress, while dynamic diachrony constitutes a mold - a template - for all possible synchronic mappings. The panchronic method is clearly connected to the grammaticalization theory (for 
However, one may not ignore the fact that the NAATA form also expresses the concepts of non-intentionality, accidentality and spontaneity of perfect or past activities. Such modally tinted values are not posited by the anterior path model. However linguistic typology does conceive an evolutionary possibility (referred to as 'evidential track') which links the grammatical life of original resultatives with determined modal domains. In accordance with this cline, resultatives develop into evidential grams following three subsequent stages: a) inferential based upon resulting visible traces; b) inferential based upon general assumption and hearsay; and c) broad non-first hand evidential (cf. LINDSTEDT 2000; JOHANSON 2000 and 2003; Aikhenvald 2004: 112-117, 279-281, and Andrason 2010). Nevertheless, the connection between the evidential value and the sense of non-intentionality, accidentality and spontaneity is far from being straightforward, and needs further studies. The attempt to explain this relation - and thus to connect the modal meaning of the NAATA gram to its source, i.e. to a resultative expression built on the verb naa 'come' - will constitute one of the future research activities conducted by the author.

\section{REFERENCES}

A Practical Orthography of Gambian Mandinka. 1988. Banjul: WEC International.

AikHenvald Alexandra. 2004. Evidentiality. Oxford: Oxford University Press.

Aikhenvald Alexandra, Dixon Robert (eds.). 2002. Studies in Evidentiality. Amsterdam: John Benjamins.

Амгот Dany (ed.). 2008. La composition dans une perspective typologique. Artois: Artois Presses Université.

ANDRASON Alexander. 2010. "The guessing QATAL - the BH Suffix Conjugation as a Manifestation of the Evidential Trajectory." Journal for Semitics 19(2), 603-627.

ANDRAson Alexander. 2011a. "The Biblical Hebrew Wayyiqtol - a Dynamic Definition.” Journal of Hebrew Scriptures $11(7), 1-50$.

ANDRAson Alexander. 2011b. "The Biblical Hebrew Verbal System in Light of Grammaticalization - the Second Generation.” Hebrew Studies 52, 351-383.

Andrason Alexander. 2011c. "Semantics of the TA Construction in Basse Mandinka." Linguistica Copernicana $6,221-244$.

AndRason Alexander. 2012a. "When imam Perfect 'Becomes' a Past." Balkanistica 25, 75-103.

ANDRASON Alexander. forthcoming 2012b. Introducción a la gramática del mandinka de la región de Basse (Introduction to the Grammar of Basse Mandinka).

ANDRAson Alexander. in review 2012c. "The Meaning of the YE Constructions in Basse Mandinka." Philologia.

Austin John Langshaw. 1962. How to Do Things with Words. Oxford: Clarendon Press.

Brisard Frank, Östman Jan-Ola, Verschueren Jef (eds.). 2009. Grammar, Meaning and Pragmatics. Amsterdam-Philadelphia: John Benjamins.

Bybee Joan, Perkins Revere, Pagliuca William. 1994. The Evolution of Grammar. Chicago-London: The University of Chicago Press.

Colley Ebrima. 1995. Mandinka Grammar Manual. Banjul: Peace Corps The Gambia.

Creissels Denis. 1983. Eléments de grammaire de la langue mandinka. Grenoble: ELLUG.

CReISSEls Denis. 2007. "A Sketch of Bambara Argument Structure." Workshop Grammar and Processing of Verbal Arguments. Leipzig, April 20-21, 2007.

Creissels Denis. 2008. "L'incorporation en mandinka." In: Аміот 2008: 75-88.

Creissels Denis. 2010a. "Transitivity Alternations in Mandinka.” Workshop on Valency Classes. Leipzig, August 21, 2010.

Creissels Denis. 2010b. "The Flexibility of the Noun vs. Verb Distinction in the Lexicon of Mandinka." International Conference on Polycategoriality. Paris, October 4-6, 2010.

a detailed discussion of the concept of panchrony, its scientific origins and relation to dynamization of typology, see ANDRASON 2010, 2011a and especially 2011b). 
Croft William, Cruse Alan. 2004. Cognitive Linguistics. Cambridge: Cambridge University Press.

DAHL Östen (ed.). 2000. Tense and Aspect in the Languages of Europe. Berlin-New York: Mouton de Gruyter.

Dramé Man Lafi. 2003. Parlons mandinka. Paris: L'Harmattan.

Evans Vyvyan, Green Melanie. 2006. Cognitive Linguistics: an Introduction. Edinburgh: Edinburgh University Press.

Gamble David. 1987. Elementary Mandinka (Gambian Studies 20). San Francisco: Gamble.

Haspelmath Martin et al. (eds.). 2001. Language Typology and Language Universals. Berlin-New York: Walter de Gruyter.

Heine Bernd, Nurse Derek (eds.). 2000. African Languages. Cambridge: Cambridge University Press.

JOHANSON Lars. 2000. "Viewpoint Operators in European languages.” In: DAHL 2000: 27-187.

Johanson Lars. 2003. "Evidentiality in Turkic.” In: AikHENVALd \& Dixon 2003: 273-291.

Kambey Kotoo (Old Testament). 1998. Banjul: WEC International.

Kambey Kutoo (New Testament). 1989. Banjul: WEC International.

KastenHolz Raimund. 1996. Sprachgeschichte im West-Mande: Methoden und Rekonstruktionen. Köln: Rüdiger Köppe Verlag.

Lewis M. Paul (ed.). 2009. Ethnologue: Languages of the World. Dallas: SIL International.

LindSTEDT Jouko. 2000. “The Perfect - Aspectual, Temporal and Evidential.” In: DAHL 2000: 365-383.

Lück Marlies, Henderson Linda. 1993. Gambian Mandinka: a Learning Manual for English Speakers. Banjul: WEC International.

Macbrair Maxwell. 1842. A Grammar of the Mandingo Language. London: The Wesleyan-Methodist Missionary Society.

Mandinka English Dictionary. 1988. Banjul: WEC International.

Mandinka English Dictionary. Revised edition. 1995. Banjul: WEC International.

Mandinka Learning Manual. 2002. Banjul: WEC International.

NiKIFORIDOu Kiki. 2009. "Constructional Analysis.” In: BrisArD et al. 2009: 16-32.

Nurse Derek. 2008. Tense and Aspect in Bantu. Oxford: Oxford University Press.

Rowlands Evan. 1959. A Grammar of Gambian Mandinka. London: SOAS.

Selections from the Writings of the Promised Messiah. 1988. Tilford: Islam International Publications LTD.

Vydrine Valentin, Bergman Ted, Benjamin Matthew. 2000. Mandé Language Family of West Africa: Location and Genetic Classification (SIL Electronic Survey Report). Dallas: SIL International.

WaltKe Bruce, O'Connor Michael. 1990. An Introduction to Biblical Hebrew Syntax. Winona Lake: Eisenbrauns.

Williamson Kay, Blench Roger. 2000. "Niger-Congo.” In: Heine \& Nurse 2000: 11-42.

WiLson William. 2000. “Creissels’s Mandinka Grammar.” Journal of West African Languages 28(2), 109-124. 